\section{Category}

Metal-Catalyzed Asymmetric Synthesis and Stereoselective Reactions

\section{Key words}

\section{rhodium}

kinetic resolution diamine ligands
M.-K. LEMKE, P. SCHWAB, P. FISCHER, S. TISCHER, M. WITT, L. NOEHRINGER, V. ROGACHEV, A. JÄGER, O. KATAEVA, R. FRÖHLICH, P. METZ* (TECHNISCHE UNIVERSITÄT DRESDEN UND WESTFÄLISCHE WILHELMS-UNIVERSITÄT MÜNSTER, GERMANY; TOMSK POLYTECHNIC UNIVERSITY, RUSSIA)

A Practical Access to Highly Enantiomerically Pure Flavanones by Catalytic Asymmetric Transfer Hydrogenation Angew. Chem. Int. Ed. 2013, 52, 11651-11655.

\title{
Rhodium-Catalyzed Asymmetric Transfer Hydrogenation
}<smiles>[R17]Oc1ccc(C2CC(=O)c3ccccc3O2)cc1</smiles>

up to $0.373 \mathrm{mmol}$<smiles>O=C1CC(c2ccc(O)cc2)Oc2ccccc21</smiles>

up to $50 \%$ yield up to $>99 \%$ ee

Selected examples:

Significance: Chiral flavanone moieties are among the largest secondary metabolites in plants. As such, they have been known for their antifungal, antibacterial, and antiviral effects. The authors present a practical and convenient method for the synthesis of both enantiomers of this class of molecules.
Comment: The catalytically active rhodium hydride species was generated in situ prior to the addition of the substrate. This method allowed the authors to reduce catalyst loading to $0.5 \mathrm{~mol} \%$ while retaining high enantioselectivities. They were able to synthesize both enantiomers of the natural product glabrol.

SYNFACTS Contributors: Mark Lautens, Zafar Qureshi 